Bulletin of Taras Shevchenko National University of Kyiv. Public Administration, 1(15), 20-23.

UDC: $351 / 354(4)$

DOI: doi.org/10.17721/2616-9193.2022/15-4/9

Maryna Kutepova, Graduate Stud.

Taras Shevchenko National University of Kyiv, Kyiv, Ukraine https://orcid.org/0000-0002-8560-8001 e-mail: marynakutepova8@gmail.com

\title{
DEVELOPMENT OF CONTEMPORARY DEVOLUTION PROCESSES IN GREAT BRITAIN
}

The main purpose of the article is to analyze the devolutionary processes in Great Britain, which have intensified and institutionalized since the late twentieth century and continue to the present days, as well as their impact on the political and socio-economic development of its member countries - England, Wales, Scotland and Northern Ireland.

Theoretical and methodological basis of the study are scientific methods and methodological approaches to understanding the process of interaction of public authorities under conditions of devolution. An important condition of the chosen research strategy is the observance of the principles of objectivity, multifactoriality and systematicity. The study is based on methodological principles of a systematic approach. Using a systems approach makes it possible to study the interaction of public authorities in the UK in the context of devolution as a single system. Based on the fact that devolution involves the creation of certain institutions, as well as institutional adaptation to a management system that adapts to new conditions, the main methodological approach to analysis was the institutional approach.

The article emphasizes that for a long time the United Kingdom has been a model of decentralized political governance based on the culture of civil society and the representation of local interests in the national government. To a large extent, Britain's sustainable development depends on a periodic political compromise. It can alleviate the main contradiction of the British political system - the dichotomy of the principles of the supremacy of parliament and regional self-government.

It is proved that the decentralization of public administration in the UK means the devolution of central government and increasing the responsibility of local government in the expansion and development of various forms of interaction between state and society. In general, the process of decentralization of power in the UK is complex and ambiguous one. The process of devolution in the UK is characterized by asymmetry, as evidenced by the lack of legislative powers of England. In this context, it is stated that the procedure of interaction between public authorities at different levels is not well established. Today there is a significant number of control functions, levers of administrative and financial pressure on central offices, as well as the lack of clear recommendations by which local authorities could determine what is within their competence and address urgent issues more effectively.

Keywords: devolution, decentralization, Great Britain, government, regions, regionalization.

Introduction. Over the last decade, a feature of government processes in many European states has been the decentralization of power in various forms - federalization, regionalization and devolution of powers. In the UK, a system of centralized control combined with decentralized decision-making through separate government agencies for countries and regions of the UK has evolved over many decades. However, the ability of the countries and regions of the United Kingdom (England, Wales, Scotland and Northern Ireland) to reflect territorial priorities in policy or in addressing local financial issues has been limited. From this point of view, Great Britain, despite the devolution, retained its status of a classical unitary state.

It is also important that the devolutionary processes in Northern Ireland, Scotland and Wales in the late 1990s could be seen not simply as administrative decentralization, but also as a radical withdrawal - the change of constitutional mechanisms that provide greater territorial autonomy in policy development and implementation. However, from a constitutional point of view, "Britain is halfway", because in England, where more than 80 percent of Britain's population lives, there is no separate decentralized parliament or assembly. However, although major political parties and scholars widely acknowledge that the system of government in England, including the balance of power between central and local government, needs fundamental change. However, there is no consensus on the form in which such a change should take place.

Based on the relevance of the research topic, the main purpose of the article is to analyze the devolutionary processes in Britain, which have intensified and institutionalized since the late twentieth century and continue to the present day, as well as their impact on the political and socioeconomic development of its member countries - England, Wales, Scotland and Northern Ireland.
Sources. The problem of decentralization of public administration has long been of interest to researchers. First, they analyze the meaning of the term "decentralization", which is defined as the process by which powers, functions, responsibilities and resources are transferred from central government to regional and local governments. It should be noted that the decentralization process is a common trend in almost all European countries. There is a general tendency to strengthen relations between regional and local governments and the central government. However, this movement is not uniform and linear one. In EU countries, decentralization takes various forms, based on the ideas and values shared by all EU member states: selfgovernment, civic participation and proximity to government.

To date, scholars have developed a number of theories that explain the causes and consequences of power devolution and resources from central to subnational governments. Among the scholars who have studied various problems and prospects of decentralization in the UK and EU countries are: S. Ayres, S. Bellamy, J. Baldersheim, H. Braibant, M. Drakeford, J. Whitaker, M. Drakeford, B. Lockwood, J. Monson, H. Mintzberg, J. Pierce, F. Porceley, M. Profiroiu, L. Rose, J. Ruano, D. Jacobsen.

Methodology. One of the main ideas of the contemporary concept of governance, aimed at improving the efficiency of public administration, is decentralization, which involves the transfer of powers and responsibilities from the central government to lower levels of government and the private sector. In public administration, decentralization is usually seen as the process by which powers, functions, responsibilities and resources are transferred from central to local governments. From a practical point of view, decentralization can help to achieve a balance between the requirements of the periphery and the requirements of the centre. Decentralization can help solve such problems as 
national unity and indivisibility, protection of national interests and ensuring coordinated and balanced development, equity in the distribution of resources, development of local autonomy, etc. [4].

It should be noted that decentralization can be applied to all types of state sovereignty, but in different forms and to different degrees. Thus, decentralization is characteristic of both federal and unitary states.

In the UK, the reform of decentralization of power was called "devolution" (from the English. devolve - to transfer), by this way the term has been entrenched in the process of regionalization in the United Kingdom.

Theoretical and methodological basis of the study are scientific methods and methodological approaches to understanding the process of interaction of public authorities under conditions of devolution. An important condition of the chosen research strategy is the observance of the principles of objectivity, multifactoriality and systematicity.

The study is based on methodological principles of a systematic approach. Using a systems approach makes it possible to study the interaction of public authorities in the UK in the context of devolution as a single system.

Based on the fact that devolution involves the creation of certain institutions, as well as institutional adaptation to a management system that adapts to new conditions, the main methodological approach to analysis was the institutional approach. The institutional approach is one of the most effective in studying political processes related to individual territories, states and regions. This approach focuses on political institutions, mechanisms of separation of powers and rules of political decision-making. The institutional approach is also an important methodological basis for revealing the theory of multilevel governance, which most fully reflects the essence of devolution in the UK.

Results. Despite the fact that due to a certain limitations of power at the regional and local levels, the UK is seen as an example of a unitary state in which the sphere of political decision-making is dominated by central government institutions. However, the form of government and the actual system of government in the UK by the end of the 1990-s was significantly modified in the policy of regionalization and decentralization in the form of devolution.

In this context, it should be noted that the devolution policy is based on the principle of dispersion of management functions, which involves the transfer of power to the territorial level of the respective regions and the creation of an asymmetric set of territorial management structures endowed with functions and certain powers to regulate [2, c. 582].

At this time, the United Kingdom has developed a system of governance based on the principle of asymmetric devolution, in which political responsibility is unevenly distributed between the central government and regional administrations [6, c. 151].

Any division of responsibilities between different levels of government leaves some inconsistencies and differences, even in settlements with much more systematic approaches than in the United Kingdom. The lack of a written constitution in the UK and a more evolutionary and flexible approach to public administration transformation have been recognized as beneficial.

It should be noted that since the establishment of the Scottish Parliament and the National Assembly for Wales in 1999 and the Assembly of Northern Ireland in 1998, there have been significant changes in the initial arrangements. In all three cases, there were changes in responsibilities initially established during the transfer of power, while in the case of
Wales, the new Welsh Government Act, adopted in 2006, was needed to streamline the initial agreement (transfer of property), and the beginning of the process of gradual acquisition of primary legislative powers. For many researchers, this is a sign of either a flaw in the original agreement or an inherent and threatening instability that has intensified in the United Kingdom. For others, the change was more a testament to the positive opportunities promised by devolution than a signal of any inalienable threats it may pose, demonstrating the flexibility of a broader constitutional settlement and its response to public sentiment and the various circumstances that may arise [6, c. 152].

The peculiarities of devolution in Great Britain are due to the influence of internal and external factors, in relation to which the determining role belonged to internal factors. Endogenous factors are associated with the preservation of internal problems of the regions, uneven socio-economic development and growing influence of the ethno-regional elite, which offers its own interpretation of the state of affairs and prospects for regional development. External, exogenous factors are linked to processes such as globalization and European integration, on the one hand, and differentiation and regionalization, on the other.

For a long time, the United Kingdom has been a model of decentralized political governance based on a culture of civil society and the representation of local interests in national government. However, we must take into account the fact that the position of local government in the British Constitution is ambiguous.

It should also be borne in mind that Britain has begun the process of decentralization in order to reduce territorial and ethnic tensions and preserve the unity of the country. It is believed that the UK has used the model of "devolution" as the maximum possible measure of decentralization, affecting the legislature, as well as its independence in some matters. However, despite the regions gaining higher status, the nature of these "states within a state" remains unitary [8, c. 479].

Ukrainian researcher of decentralization of power $\mathrm{V}$. Velychko is convinced and gives an interesting example of the fact that in a number of states the term "local selfgovernment" is not used at all. For example, "in Great Britain, Japan, and Israel, which are decentralized unitary states, there is no local self-government, as such functions are performed exclusively by residents of administrativeterritorial units, and there are no local authorities. In view of this, the term "local government" is used in such countries. It should be noted that there is the opposite situation, when, on the contrary, there are no local governments, and at all levels of government there are public authorities. A striking example of such a centralized unitary country is China. As for Ukraine, it belongs to the relatively decentralized unitary states, where at the local level there are both local governments and public authorities" [9].

In this context, the position of Council of Europe expert J. Jackson on the experience of decentralization reform in the United Kingdom is noteworthy. The expert, in particular, notes that in the UK, clearly and correctly defined evaluation indicators. They are included in the British legislation governing the relationship between central government and local government, have established appropriate standards of work of the government elected by the citizens "benchmarking". According to J. Jackson, benchmarking "extends to three areas of local government functions: their institutional capacity, providing services to the population and involving the community in the work of its elected local authorities" [7]. 
According to $\mathrm{J}$. Jackson, the application of this method gives a real picture of the activities of local government, as well as answers topical questions about the problems of centralized management and its reform. This method can be used to determine whether the partnership of the nongovernmental sector with the government is real [7].

At the beginning of the XXI century local government has acquired new features, which is associated with growing interest in this issue. The British researcher J. Chandler identifies the current importance of local government in two important ways: 1) the ability of local authorities to coordinate many individual functions and choose a strategy for the development and well-being of the community as a whole; 2) the fact that local government is the only agent that represents the interests of local communities at the national level [5, c. 2].

A striking fact in the process of decentralization reform in Britain is that Britain is the only British entity that has not acquired legislative power and its own parliament. England has always been the most developed part of Britain, on which the future of the devolution largely depended.

It should be noted that within the framework of political decentralization in the United Kingdom, an intermediate model of federalization was implemented, which consisted in maintaining the principle of the inviolability of a unitary state, called devolution. The essence of the current stage of devolution in the UK is the choice of a model and political strategy for the transition to a broader strategy of expanding the sphere of self-government of regions and their participation in political decision-making and policy development. However, decentralization in the form of federalization remains outside of the real strategic perspectives of the United Kingdom.

One of the features of devolution in the UK is the decisive influence of internal rather than external factors. Because of this, England has implemented a model of administrative decentralization, rather than functional devolution, as has been the case in other regions. Administrative devolution involves the redistribution of administrative functions in the sphere of regulation, primarily economic activity, and their transfer to eight metropolitan cities in England. At the present stage, a combined political strategy of administrative and partly functional devolution is being implemented in this region. The strategy is based on the concepts of convergence and localism. According to this, the model of administrative devolution is aimed at overcoming the uneven economic development of territories through the development of megacities. The latter are a kind of pilot projects to test and implement the most effective management technologies [1].

The autonomy of the national regions of Great Britain and its absence in England strengthened the asymmetry of the territorial structure of the unitary state. Members of the British General Assembly have repeatedly called for the creation of a "Great English Committee" or "English Parliament". However, these demands were rejected due to fears that politically strong and developed England would dominate other territories, causing clashes between national and regional parliaments. As early as 1973, the Royal Constitutional Commission declared that the federation, consisting of four units: England, Scotland, Wales and Northern Ireland, would be unbalanced and inoperable. Devolution in the UK as a process typical of unitary systems has led to a new form of territorial distribution of power that combines decentralization and asymmetric distribution of power on a federal basis. According to a number of researchers, the most likely option for the development of the United Kingdom will be further regionalization, for example, with the empowerment of the regions of England greater powers [3, c. 16]

Discussion and conclusions. Thus, constitutional mechanisms in some parts of the UK have been transformed as a result of political decentralization. The United Kingdom has moved to asymmetric governance with regional autonomy for Scotland and Northern Ireland, a unitary regime for England and to a lesser extent for Wales, as Wales lacks proper legislative power after the Welsh Act of 2006. The UK Government is strengthening the development of the regions, paying attention to the inclusion of regional priorities, funding many regional projects and programs, and developing a more effective regional strategy.

Although the constitutional order in some parts of the UK has been changed by the political devolution in England, the government is still taking a more cautious approach based on strengthening the regional level through administrative decentralization. In England, unlike other regions of Great Britain, the emphasis was on strengthening the regional level through administrative decentralization. Nevertheless, such reforms are a significant strengthening of the mechanism of regional governance and open up opportunities for the transformation of intrastate relations. In general, the implications of increased regionalization for the government have not been fully understood. The need to place greater emphasis on regional development in the formulation of national policies and to adopt a more coordinated approach to the development and implementation of a regional strategy was recognized.

Consequently, the internal political, socio-economic and cultural aspects of the development of regions in the United Kingdom remain uneven, which is connected to a certain extent with the asymmetric nature of the devolutionary transformations. Prerequisites are being created and institutional mechanisms are being worked out for the transition from administrative to a possible functional devolution of governance in the regions, the main content of which is the expansion of the powers of subregional institutions and local administrations, primarily in the economic sphere. The combined political strategy of administrative and partially functional devolution in England is in a certain sense based on the concept of convergence and is aimed at overcoming the uneven economic development of territories through the development of megacities and considering them as experimental stands for testing and implementing the most effective management technologies.

The main vector in British politics in the near future will be the dominance of issues related to constitutional law, in which issues of devolution and regional development are of paramount importance, along with traditional issues of relations with the EU. Against this background, remaining somewhat hidden in the shadows, the problem of harmonizing the British constitutional convention stands out. This problem reflects and consolidates in the legal field the idea of federalization and, as an inevitable component of this process, the reform of the House of Lords. In addition, the problem of relations with the EU on Brexit comes to the fore.

The model of devolution in the UK is based on the principle of dispersal in a certain sense of the variant dispersion of managerial functions, depending on the specifics of the region. The model provides for the transfer of part of the powers to the territorial level of the respective regions and the creation of an asymmetric management model, within which the regions are endowed with separate functions and certain powers to regulate processes, primarily in the field of economics 
and social relations, on the principle of clearly limiting the spheres of influence of regional and local authorities.

Thus, the decentralization of public administration in the UK means the devolution of the central government and increasing the responsibility of local government with the expansion and development of various forms of interaction between the state and society. In this context, devolution is primarily a process of transferring power from the central to the lower level. It was devolution that became the most important event of the last decades in the political and socioeconomic development of Great Britain. Unlike decentralization, devolution aims at a more significant transformation of the territorial system of government - the transfer of not only executive powers, but also some legislative ones.

Consequently, the decentralization of power, which has signs of devolution in the UK, is complex and ambiguous. The process of devolution in the UK is characterized by asymmetry, as evidenced by the absence of the legislative powers of England. In this context, the lack of wellestablished procedure for interaction between public authorities at different levels is stated. Today there are still a significant number of control functions, levers of administrative and financial pressure on central offices, as well as the lack of clear recommendations by which local authorities could determine what is within their competence and address urgent issues more effectively.

\section{References}

1. Artomanova E, Lukin V., Musienko T. (2015) Britanskaya model regionalizatsii i detsentralizatsii vlasti [The British model of regionalization and decentralization of power.]. Zhurnalnyiy klub Intelros "Credo New" [Intelros magazine club "Credo New"]. №4. URL: http://www.intelros.ru/ readroom/credo_new/kre4-2015/28730-britanskaya-model-regionalizacii-idecentralizacii-vlasti.html [in Russian].

2. Ayres S., Pearce G. (October 2005) Building regional governance in England: the view from Whitehall. Policy \& Politics. Vol. 33. N 4. P. 581-600.

3. Bogatyireva O.N. (2018) Protsessyi detsentralizatsii v evropeyskih stranah [Decentralization processes in European countries]. Elektronnoe prilozhenie $k$ Rossiyskomu yuridicheskomu zhurnalu [Electronic appendix to the Russian legal journal]. №2. C.5-20. [in Russian]

4. Braibant G. (1985-1986) Institutions Administratives Comparees: Les Controles. Fondation nationals des Sciences politiques, Services de Polycopies, Paris. P. 89 -93.

Вісник Київського національного університету імені Тараса Шевченка. Державне управління, 1(15), 20-23.

удК: $351 / 354(4)$

DOI: https://doi.org/10.17721/2616-9193.2022/15-4/9

Марина Кутепова, асп.,

Київський національний університет імені Тараса Шевченка, Київ, Україна

https://orcid.org/0000-0002-8560-8001

e-mail: marynakutepova8@gmail.com

\section{РОЗВИТОК СУЧАНИХ ПРОЦЕСІВ ДЕВОЛЮЦІї У ВЕЛИКОБРИТАНІЇ}

Проаналізовано деволюційні процеси у Великій Британії, що посилились та інституціоналізувалися з кінця XX ст. і тривають до сьогодні, а також їх наслідок для політичного та соціально-економічного розвитку країн, що входять до їі складу - Англії, Уельса, Шотландії та Північної Ірландії.

Теоретико-методологічну основу дослідження становлять наукові методи та методологічні підходи до осмислення процесу взаємодії органів державної влади в умовах деволюції. Важливими умовами обраної дослідницької стратегії є дотримання принципів об:єктивності, багатофракторності та системності. В основу дослідження покладені методологічні принципи системного підходу. Використання системного підходу дає можливість вивчати взаємодію органів державної влади у Великій Британії в умовах деволюції як єдину систему. Виходячи з того, що деволюція передбачає створення певних інститутів, а також інституційну адаптацію до системи управління, що адаптується до нових умов, основним методологічним підходом аналізу було обрано інституційний підхід.

Актуалізовано, що довгий час Велика Британія була зразком децентралізованого політичного управління, заснованого на культурі громадянського суспільства і представництві місцевих інтересів у національному уряді. Значною мірою сталий розвиток Великої Британії залежить від політичному компромісу, що періодично досягається. Він здатний пом'якшити головну суперечність британської політичної системи - дихотомію принципів верховенства парламенту і регіонального самоврядування.

Доведено, що децентралізація державного управління у Великої Британії означає деволюцію центральної влади та підвищення відповідальності місцевого управління за розиирення та розвитку різних форм взаємодії держави та суспільства. Загалом процес децентралізації влади у Великій Британії відбувається складно та неоднозначно. Процес деволюції в державі характеризується асиметрією, про що свідчить відсутність законодавчих повноважень Англії. у цьому контексті констатується недостатня налагодженість процедури взаємодії органів державної влади на різних рівнях. На сьогодні зберігається вагома кількість контролюючих функцій, важелів адміністративно-фінансового тиску на центральні відомства, а також відсутність чітких рекомендацій, за допомогою яких місцеві органи державної влади могли б визначити, що входить до сфери їхньої компетенції і, відповідно, вирішувати нагальні питання більш ефективно.

Ключові слова: деволюція, децентралізація, Велика Британія, уряд, регіони, реаіоналізація.
5. Chandler J. (1993) Local government in liberal democracies: an

7. Nahrebetska I. (2015) Dosvid reform: Velykobrytaniia [The ex-
(2). $137-155$. peforms: Great Britain]. Rada Yevropy. 25 liutoho 2015 [Council experience-in-the-united-kingdom/ [in Ukrainian].

tworks and Decentralisation in Europe. The Palgrave Handbook of . ocal self-government. Issue 28]. URL: https://dspace nlu edu ua/ оналиции и децентрализации власти. Журнальный клуб Интелрос "Credo New". 2015. №4. URL: http://www.intelros.ru/readroom/credo_new/

Богатырева О. Н. Процессы децентрализации в европейских алу. 2018 №2 С. 5-20.

ержавне будівництво та місцеве самоврядування. 2014. Випуск 28. https://dspace.nlu.edu.ua/bitstream/123456789/7492/1/Nelychko_12.pdf лютого 2015. URL: http://www.slg-coe.org.ua/reforms-experience-in-the-

5. Ayres S., Pearce G. Building regional governance in England: the Fondation nationals des Sciences politiques, Services de Polycopies, Paris, 7.

mocracies: an intro-

8. Drakeford $M$. Devolution and youth justice in Wales. Criminology \& .

and Decentralisation in Europe. The Palgrave Handbook of decentralization

Received: December 03, 2021

Published: January 31,2022
Список використаних джерел 